\title{
FRANKOWE INSPIRACJE
}

\author{
Aleksander Walczak \\ Wydział Nawigacyjny, Akademia Morska w Szczecinie
}

Retrospekcja przeżytych lat ma dwa oblicza - miłe lub przykre, do których nie chciałoby się wracać. Złożona historia naszych pokoleń - Jubilata i moich osobistych przeżyć, w tym przypadku wnoszą tylko pozytywne wspomnienia.

W wielorakim splocie różnych wydarzeń i faktów związanych z osobą Profesora Franciszka Gronowskiego w środowisku morskim i akademickim - trudno zdecydować o tym, od których zacząć. Zwłaszcza, że pewne okoliczności naszych spotkań opisałem bardzo szczegółowo z okazji 75-lecia urodzin Jubilata.

Minęło 15 lat od tamtej daty. Wydaje się, że to było wczoraj, kiedy snuliśmy wspomnienia z różnych okresów naszych kontaktów. A jednak coś umknęło i coś w pamięci utkwiło. Powoduje to potrzebę powrotu do minionych lat, podzielenia się przeżyciami dawnych wydarzeń, szczególnie tych, które są konsekwencją i wynikają z naszych naukowych spotkań.

Zanim do tego dotrę - trzeba zrozumieć tło naszych powiązań, zarówno naukowych zainteresowań morskich, jak i przyjacielskich relacji. To mój promotor, wprowadzający mnie w tajniki metod badawczych. Potem były spotkania w ramach prac w komisjach, radach naukowych i doradczych przedsiębiorstw żeglugowych, a także na kongresach, konferencjach czy sympozjach. Decydującym przełomem było spotkanie z okazji 40-lecia Wydziału Inżynieryjno-Ekonomicznego. Wtedy to padła $\mathrm{z}$ ust Profesora propozycja przejścia z wszystkimi Jego doktorantami „Na Ty”.

Była to znamienna chwila, kiedy zrozumieliśmy jaką tworzymy wspólnotę, jak jesteśmy sobie bliscy, stanowiąc jedną liczną rodzinę. Zmalała zatem 3-letnia różnica wieku między nami, a bezpośredniość zachowań Mistrza, skróciła dzielący niegdyś dystans. Od tej chwili Nauczyciel i uczeń stali się bardzo bliscy sobie, zwłaszcza, że łączyła nas także nauczycielska i naukowa profesja związana z gospodarką morską.

Moja praca doktorska dotyczyła uwarunkowań ekonomicznych wypadków i awarii nawigacyjnych. Miałem możliwość wykorzystać swoje doświadczenie zawodowe oraz wiedzę ekonomiczną ze studiów magisterskich. Powiązanie obu zagadnień - ekonomicznych i nawigacyjnych, utworzyło sensowną całość.

Praca nad rozprawą stała się inspiracją do cennych dociekań naukowych, z racji odkrytych problemów badawczych, które dotyczyły nadrzędnej roli człowieka w zakresie bezpieczeństwa żeglugi. Wśród czynników wypadków i awarii statków morskich - ludzkiego, technicznego i eksploatacyjnego, dominuje czynnik ludzki. 
W badanym przeze mnie okresie 1960-1970 wypadki i awarie jednostek polskich z winy człowieka stanowiły $61,3 \%$. Odkrycie to miało dla mnie szczególne znaczenie, gdyż pojawiło się w czasie przekształcania państwowych szkół morskich w wyższe uczelnie. Towarzyszyła temu refleksja zrodzona pod wpływem wypowiedzi prof. Jerzego Bukowskiego, przewodniczącego komisji ds. Wyższych Szkół Morskich, „czy czasem nie rezygnujemy z dobrych szkół morskich na rzecz wyższych uczelni”. Dobre przygotowanie do pracy na morzu wymagało zmiany kształcenia.

Zdałem sobie sprawę, że świat pędzi naprzód. Żegluga i okrętownictwo nie pozostaje w tyle. Trzeba było dotrzymać kroku. Były to trudne chwile, zwłaszcza, że byłem zaangażowany w działalność uczelni, jako dziekan Wydziału Nawigacyjnego, prorektor oraz rektor czterech kadencji. Spoczywał na mnie obowiązek i odpowiedzialność za losy absolwentów, stanowiących najważniejsze ogniwo kadr morskich, załóg statków polskich armatorów żeglugowych i rybackich.

Oprócz zmian organizacyjno-strukturalnych uczelni, decydującą rolę odgrywały nieliczna wówczas kadra nauczycieli akademickich. Trzeba było także zbudować bazę laboratoryjną i statki szkolno-badawcze. Wszystko to miało na celu przygotowanie wysoko wykwalifikowanych absolwentów dla floty handlowej i rybackiej.

W wykonywaniu funkcji administracyjnych wykorzystywałem doświadczenia z pracy na morzu. Na tym tle zrodziło się wiele pytań dotyczących bezpieczeństwa żeglugi. Znakomitą okazję do szukania odpowiedzi na te pytania, ale też powstanie nowych, były seminaria prowadzone przez Profesora Gronowskiego.

Tam właśnie zrodziły się koncepcje badań nad rolą człowieka w bezpieczeństwie żeglugi. Problematyka ta stała się moją pasją, a jednocześnie obowiązkiem nauczyciela akademickiego. Z moich badań nad światową gospodarką morską, rozwojem technicznym flot, doskonalenia systemów nawigacyjnych wynika konieczność ciągłej aktualizacji wiedzy kadr oficerskich przy wykonywaniu obowiązków zawodowych na różnych stanowiskach. W takich okolicznościach poza pracą doktorską powstawały moje kolejne opracowania, a ich inspiracją były spotkania z Profesorem Franciszkiem Gronowskim. Inaczej mówiąc rozpoczęła się moja nowa droga, jako autora koncepcji kształcenia w warunkach dynamicznego rozwoju nauki i techniki morskiej.

Bezpieczeństwo żeglugi to szeroki obszar zagadnień. W polu moich zainteresowań ulokowałem: analizy nawigacyjnych akwenów działalności floty handlowej i rybackiej, metody badań i dokładności pozycji statków, radaryzację torów wodnych, zastosowanie i dokładność systemów satelitarnych, wpływ człowieka i technologicznego wyposażenia statków na awaryjność nawigacyjną floty transportowej. W efekcie tego powstały opracowania w postaci monografii, podręczników, skryptów, podręczników metodycznych i artykułów naukowych, także dla potrzeb edukacyjnych. Chciałbym szczególnie podkreślić rolę tych ostatnich akcentujących problematykę badań oraz zasad kształcenia i wychowania kadr oficerskich. Rozpocząłem od Seminarium i praca dyplomowa z nawigacji (1974), rozwijając później problematykę Roli seminarium dyplomowego w uczelniach morskich (1994) oraz Zastosowanie metodologii badań naukowych w nawigacji morskiej (2005). Wyróżniało to znaczenie zmian nie tylko w strukturze szkolnictwa morskiego, lecz zaznaczało wprowadzenie dodatkowej funkcji naukowo-badawczej w wyższej szkole morskiej.

Zwracałem szczególną uwagę na szkolenie praktyczne w WSM, po uprzednim ustaleniu wzajemnego programowego układu i powiązania teorii i praktyki w przygotowanej pracy $Z a$ - 
sady praktyk morskich. Zawarłem tam argumentację z własnych wyników badań do kształcenia studentów i ich angażowania w proces prowadzenia badań. Taka synergia ma istotne znaczenie dla jakości kształconych kadr.

Podniosłem to zagadnienie także w książce O jakości kształcenia w polskich uczelniach morskich (2003), stanowiącej analizę naszej działalności edukacyjnej i jej wpływu na kwalifikacje naszych absolwentów.

Dostrzegłem wyjątkową rolę wychowawczą uczelni morskiej. W efekcie moich dociekań naukowych doszedłem do wniosku jak ważna jest osobowość człowieka w pracy zawodowej na morzu. W kilku publikacjach podnosiłem temat kształcenia wychowującego, różnice w pojęciach - kwalifikacji i kompetencji zawodowych, gdzie obok wiedzy i umiejętności, występuje świadomość swej roli i odpowiedzialności każdego członka załogi za podjęte decyzje i realizowane zadania.

Ten utrzymujący się background uzyskany na seminariach u Profesora Gronowskiego przeniosłem także na forum międzynarodowe. W latach 1984-1990 będąc przedstawicielem Polski do Międzynarodowej Organizacji Morskiej w Londynie współpracowałem nad projektem Konwencji STCW 1978/1995, dotyczącej „Wymagań w zakresie wyszkolenia marynarzy, wydawania im świadectw oraz pełnienia wacht”․ Wniosłem swoje uwagi, wynikające z badań, które rozpocząłem w roku 1970 pod kierunkiem Jubilata. Jako pierwszy na świecie opracowałem w języku narodowym „Konwencję STCW - 79 znowelizowaną w 1995 roku, jej główne postanowienia i propozycje wdrożeń w Polsce” (1996). Ale nie tylko to. Przybliżyłem polskiemu czytelnikowi rolę i znaczenie, dla bezpieczeństwa żeglugi, organizacji międzynarodowych przez publikacje w polskich wydawnictwach naukowych i zawodowych (A. Walczak, Międzynarodowa Organizacja Morska. International Maritime Organization - IMO, Wyd. WSM, Szczecin, 1987). Nie pominąłem także funduszu odszkodowawczego FUND oraz zastosowania informatyki w praktyce eksploatacyjnej (A. Walczak, Udziat Międzynarodowego Funduszu Odszkodowawczego w pokryciu szkód spowodowanych zanieczyszczeniem olejowym /IOPC FUND/ w latach 1979-1986, Zeszyty Naukowe WSM nr 33, Szczecin, 1988). Znaczenie człowieka w działalności na morzu, zaprezentowałem w publikacji The effect of human factor on the frequency of navigational accidents (University of Southampton UK 1996).

Pominę statystyki badań potwierdzające znaczenie prezentowanych opracowań dla kształcenia polskich i obcych armatorów. Utrzymujemy się na wysokiej międzynarodowej pozycji w jakości wykształconych kadr. Nasi absolwenci nie mają trudności w zatrudnieniu i są cenieni na rynku żeglugowym świata.

$\mathrm{Na}$ koniec chciałbym o nich wspomnieć w aspekcie bezpieczeństwa pływania, niezależnie pod jaką banderą. Dotyczy to terroryzmu morskiego, zagrażającego życiu naszych absolwentów. Ze względu na to zjawisko podjąłem się opracowania monografii Piractwo i terroryzm morski (2004) - analizując i przedkładając informacje i ostrzeżenia, gdzie podjąłem się nie tylko opisu metod ochrony statku, obiektów portowych, ale przede wszystkim taktyki zachowań załogi i personelu portowego na opanowanym przez terrorystów statku i podczas ataku na port. Przedstawiłem zasady zachowań i negocjacji, prezentując cele i czynniki decydujące o skutecz-

1 International Convention on Standard Training Certification and Watchkeeping for Seafarers (STCW 1978/95). 
ności rozmów negocjacyjnych. Szczególne uwagi dotyczą decyzji kapitana i zachowań załogi po zawładnięciu jednostki przez terrorystów. Problematyka ta zainteresowała także żeglarzy.

Wyniki moich badań i dociekań naukowych były przedmiotem „Strategii rozwoju szkolnictwa morskiego" (2002), przedkładanej kolejnym ministrom resortu. W tej strategii znalazły się elementy naszych dyskusji tematycznych i licznych rozmów nieformalnych.

Trudno przedstawić całą problematykę prac badawczych, które podjąłem z inspiracji Jubilata i wyniesionych doświadczeń z moich pierwszych badań naukowych.

To Profesor Gronowski wprowadził mnie na ścieżkę badań naukowych, zaszczepił bakcyla dociekań poznawczych prowadzących do aktywności w poszukiwaniach i wyjaśnianiu otaczającej nas rzeczywistości.

Nie ukrywam swoich życzliwych uczuć w stosunku do Jubilata. Znajomość z Nim pozwoliła mi poznać ciekawe i intrygujące obszary wiedzy, które wzbogaciły i pobudziły moją wyobraźnię i zainspirowały mnie do podejmowania poszukiwań interesujących tematów badawczych.

Dziękuję Ci Profesorze

AT MULTOS ANNOS, Drogi Franku! 